\title{
Impact of the COVID-19 pandemic on the online educational quality in USC's school of engineering and school of cinematic art
}

DOI: $10.46932 /$ sfjdv3n1-102

Received in: Jan 30st, 2021

Accepted in: Feb 1th, 2022

\author{
Jiling Zhang \\ Annenberg School of Communication and Journalism, University of Sothern California, Los Angeles, \\ California, 90089, United States \\ E-mail: alexzhan@usc.edu
}

\begin{abstract}
This research paper demonstrates the results of a questionnaire containing a series of questions, conducted at the University of Southern California, on the educational quality via online forms during the COVID19 pandemic. The research was conducted with students from the School of Engineering and the School of Cinematic Arts. The outcome of the survey demonstrates that almost all of college students are pleased with the university's measures during the pandemic. But, negative perspectives were also reported: such as the shortage of adequate infrastructure for students and the shortage of effective communication and interaction between teachers and students, inability to make practical applications, shortage of socialization, shortage of motivation to learn, less objective exams (e.g., potential for cheating), potential for physical and mental health deterioration, and potential for health deterioration (e.g., spending too much time on online platforms, developing another lifestyle. Therefore, the university administration must take effective and efficient measures to eliminate the impact on students in the upcoming academic year. The university administration must take effective measures to eliminate these negative issues in order to improve the performance of the online education process. Improving the performance of the online education process.
\end{abstract}

Keyword: COVID 19, online application, questionnaire, teaching evaluation, degree of satisfaction.

\section{INTRODUCTION/BACKGROUND INFORMATION}

A novel coronavirus (COVID-19) was found in Wuhan (China) in December 2019 and has spread worldwide since then. High reproductive numbers and serious health implications have prompted governments to minimize disease propagation among the population. The biggest unforeseen educational experience in history has maybe been the online and remote studying in colleges and institutions worldwide. The outcomes of on-line and remote learners can influence the work of universities and colleges over a generation. The investigation demonstrates that online learning works just as well as classrooms. The status quo will probably be restored if the experiment fails. The serious and immediate economic effect of COVID-19 implies that education policy and financing choices are taken in the short term on the basis of the best facts and information available at the time. Therefore, it is important for informed policy decisions to take early assessment of information on the influence on education. There 
are transitory emergencies too. Events, and yet at this time overwhelming and important, recollections can quickly fade. As with other disaster investigations, a quick response is required.

There are advantages and disadvantages to the entire experience for University of Southern California (Trojans) students, who receive live and recorded lectures. Students are happy to work from home since they feel at ease at home and like to work at their workstations. You save time. You save time. Without having to worry about the travel you can sleep more. Many pupils have no quiet place at home, on the other hand. They have no office, a loud atmosphere, childcare and domestic functions and internet entertainment while Students. All day. Students online. It is difficult for many trojans to be motivated to study at a distance. There are some reasons why there is no community, loneliness, lack of friends, and not exercise. Apart from simple matters, students are battling to express what they do not grasp, thus they develop into extensive emails. While some students struggle with deadlines at most, the lack of the framework of programs and routines in their life poses much more problems. Time limits are further exacerbated by short-term change from well-meaning teachers, occasionally affecting well-organized pupils. Students often reported significant levels of tension and worry; they expressed concern over course completion and the influence on their grades of distant learning. However, it is more complete than that; depending on their circumstances, students juggled distant study, childcare and jobs. Students and family members leave paid employment and find themselves unsafe sometimes under financial strain. Young students who had previously felt invincible suddenly feel vulnerable to a world they never anticipated, returning to their parents and fearing both their family and friends for security. There are likely to be mental health concerns and Many institutions and colleges have established advisory resources. The situation is worse for overseas students: staff and students, harassment and discrimination based on China's interpretation of the virus.

Other challenges exist: The jet lag is particularly tough for students who are back from North America in Asia, Europe or Middle East. The lack of email and online communication symbols increases student stress for those whose primary language is not English, affecting motivation and commitment. Students in certain areas of South Global are not going back to college, since they do not have enough internet infrastructure to ensure their distance from their home nations. Many overseas students struggled to locate interim schools once the campus closed and remained. Site lodging. Site lodging. They are also emotionally disturbed and concerned at home about their families. The returning people are worried about whether they may return to school in the autumn of 2020, in the face of major uncertainty around overseas service limitations. Student and graduate research programs will also be affected. Projects requiring laboratories or other facilities will be based on an exchange of ideas and participants' observation or on foreign travel. The defense was hard since the unexpected change struck instructors and students. Some 
professors and students discovered remote advice via video or mesas. effective, primarily when controversial issues arose.

\section{LITERATURE REVIEW}

The effectiveness of offering online courses in an emergency is frequent. There are no quantifiable differences between normal class and emergency instruction in learning outcomes and test performance in general. Be a pupil. Disruptions at the start of the academic year may have less impact than preexamination interruptions [3]. Women usually get worse with testing and most males get greater results with testing [2]. But most students attending on-line courses are unwilling to embrace online courses. courses. Courses exhibit a vital interpersonal link between students and teachers throughout the course breaks [5]. Students nevertheless appreciate the efforts of the institutions and faculty to ensure academic continuity. There is little evidence to indicate influence on student enlistments in Italy following the earthquake. Students may be worse than they look, and the mental health of instructors may be affected. Students might postpone their education and are more likely to leave the school [1].

Online emergency teaching promotes online models of good practice by establishing good working contacts with staff in educational technology, providers of learning resources and training and opportunities for teachers and for professional development. Positive attitudes, student and colleague professorship and fast judgments are helpful. It is crucial that teachers, students and teachers communicate well. They facilitate the prediction of final grades, and in certain circumstances a statistically relevant connection between online assessments and supervised final examinations. However, emphasis on grading risks excluding the evaluation function in assessing the success of the student against learning goals. Learning techniques based on experience like trips, foreign study, non-profit learning and practical projects provide specific problems for the breaks of the lessons.

\section{MATERIAL AND METHOD}

\subsection{RESEARCH QUESTIONS}

1. To what extent do you think the University of Southern California's actions during the coronavirus is effective towards the continuity of the educational procedure?

2. From "very good" to "very bad", how do you rate the online teaching, learning and assessment experience in University of Southern California during the pandemic?

3. One option for developing the educational procedure in the 2020-2021 academic year is to combine traditional (personal) education with online education. Given the students' learning needs, what do you think of this option? 
4. What would be the benefits of a combination of teaching and online teaching?

5. What would be the downsides of a combination of teaching and online teaching?

6. Could you illustrate your perspective on online education given the experience during the pandemic?

7. For future considerations, what would be the primary benefits of online teaching?

8. For future considerations, what would be the primary disadvantages of online teaching?

9. What factors do you think that online teaching resources and content are useful?

10. What did the students like about the online test / assessment? (Open-ended)

11. What is the disadvantage of the online exam / assessment? (Open-ended)

\subsection{RESEARCH METHODS}

Contamination of the typical training process was substantially affected by the pandemic and the administrative action taken at various levels to prevent the spread of pandemic's infection. Online knowledge dissemination and usage for online activities using relevant technology. This study aimed mainly at examining the attitudes of USC students about online education as they had never before met this kind of learning (i.e. Bachelor and Masters' degrees). In USC, the most classic should be noted. The way in which education takes place is face to face. This study also does not seek to validate or reject certain hypotheses, but instead, via input from its students, to assess USC's online education situation as the basis for urgent change at the start of the new academic year and future research.

The target market includes students from two universities: Viterbi (degrees and masters) Engineering School and Communication School (Annenberg). The two schools have been chosen according to their specialization, because the laboratories are used in various fields. The call was shared with us using a WhatsApp program. Communication groups for students and teachers which existed in both schools and data were gathered for two weeks at school. Two hundred and five students (125 from Viterbi and 80 from Annenberg) participated in the study and discovered important patterns in their view of online platform quality in the educational process.

Survey technique used as a tool with a questionnaire. The online application Google Forms was used to evaluate students' view of the high quality in education on the web platform through an anonymous online survey. There were 11 questions in the survey. The students had to pick or assess numerous alternatives using a grade level. Nine of the poll questions were closed. Students were instructed to answer two more open questions offer instances of technologies they found particularly beneficial for closed-term online learning, including advantages and disadvantages of online examinations. The Google Forms application automatically captured and statistically analyzed the data and then imported it into an Excel 
software. Data are then loaded to Excel to make it easier to analyze and comprehend for explicit graphic representation.

\subsection{FINDINGS}

Figure 1. Question 1: To what extent do you think the University of Southern California's actions during the coronavirus is effective towards the continuity of the educational procedure?

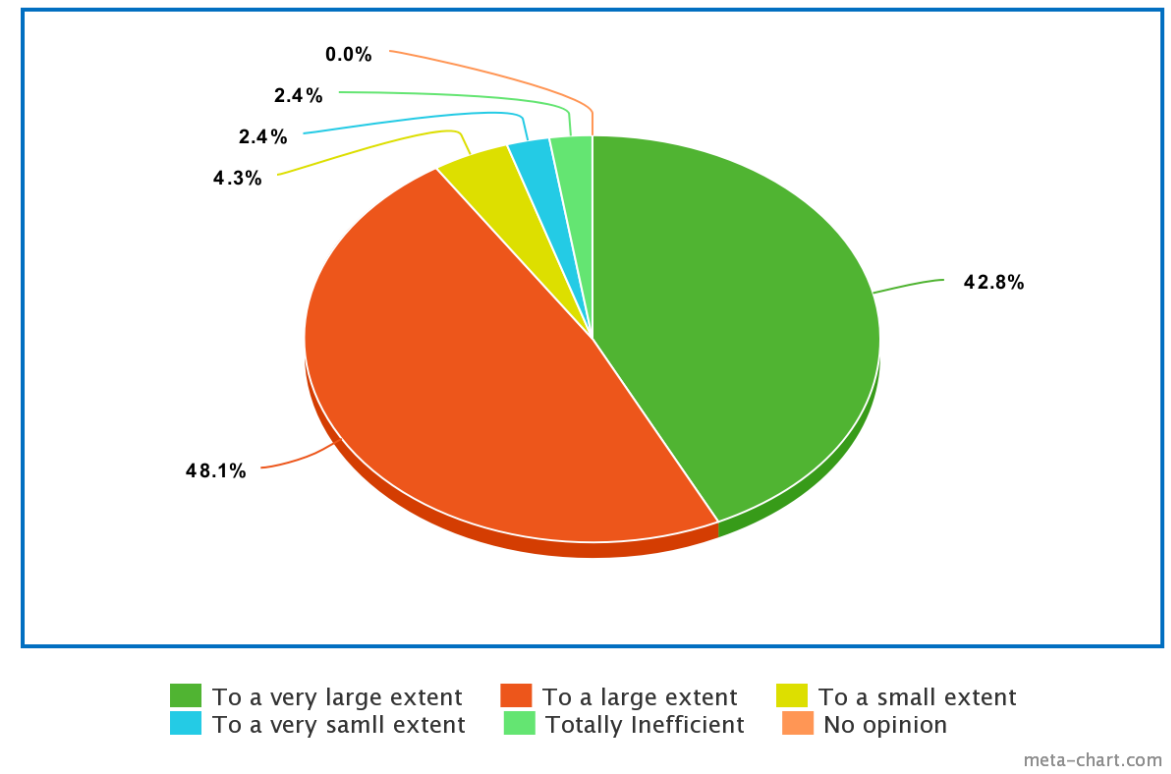

According to the results from Figure 1, the majority (90.9 percent) said that there were sufficient and effective steps taken by the University of Southern California to ensure the continuity of the teaching method (Question 1) during the pandemic of COVID-19. And just a few (9.1 percent) said the contrary.

Table 1. Question 2: From "very good" to "very bad", how do you rate the online teaching, learning and assessment experience in University of Southern California during the pandemic?

\begin{tabular}{|c|c|c|c|c|c|}
\hline $\begin{array}{l}\text { Items for qualifying the online } \\
\text { experiments }\end{array}$ & $\begin{array}{l}\text { Very } \\
\text { Good }\end{array}$ & Good & Neutral & Bad & $\begin{array}{l}\text { Very } \\
\text { Bad }\end{array}$ \\
\hline Possibility to connect to the Internet & 82 & 67 & 38 & 13 & 5 \\
\hline $\begin{array}{l}\text { Availability of digital equipment } \\
\text { (phone/tablet/laptop/computer) }\end{array}$ & 82 & 69 & 36 & 15 & 3 \\
\hline $\begin{array}{l}\text { Availability and utility/efficiency of } \\
\text { the online platform }\end{array}$ & 86 & 65 & 37 & 13 & 4 \\
\hline $\begin{array}{l}\text { Interaction and communication with } \\
\text { teachers }\end{array}$ & 77 & 60 & 42 & 14 & 9 \\
\hline Quality of online learning content & 73 & 64 & 45 & 15 & 8 \\
\hline Motivation to learn & 55 & 60 & 48 & 27 & 15 \\
\hline Assessment examination & 83 & 66 & 40 & 12 & 4 \\
\hline
\end{tabular}


According to the results from table 1, three students stated this was "deplorable" with regards to the availability of the infrastructure, but 15 students indicated that the availability of digital devices is "bad" with regard to the ability to connect to the Internet. These pupils do not, as they stated, have access to internet platforms. While the majority of students (90\%) felt that they have the required facilities, the two following items showed that contact with instructors was not successful. I believe even neutral replies indicate what misunderstandings are. On the one hand, the lack of enthusiasm of the students in teacherstudent contact might be the result of this "short circuit" Learn how to achieve the lowest outcomes with the kids. Another explanation may be the absence of instructor experience in online training. The latter approach is somewhat supported by student reactions to the quality of information for online learning. Teachers may not have the time (everything is done quickly), and some may not even have the ability to develop the best online learning content to hold student interest on the screen. Question of assessment / online examination, most pupils fulfilled by your replies in the table (72.6 percent ). 19, 5 percent of students had a neutral attitude that might imply that the grades/assessment methods they got were slightly unsatisfied or represent an objective performance analysis and a lack of engagement.

Figure 2. Question 3: One option for developing the educational procedure in the 2020-2021 academic year is to combine traditional (personal) education with online education. Given the students' learning needs, what do you think of this option?

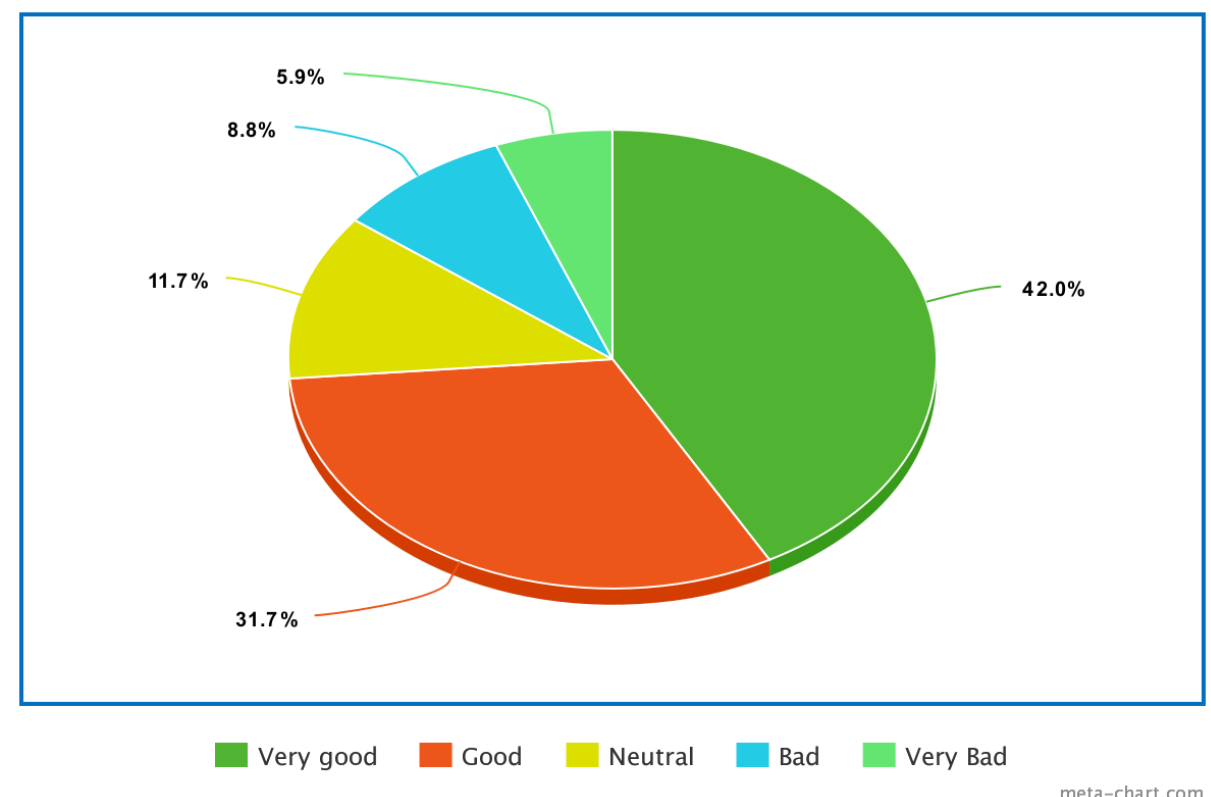

According to the results from figure 2, the question raised in the study was that conventional education and online education might be combined in the academic year 2020-2021. The majority of pupils $(73,7 \%)$ agree that $11,7 \%$ are indifferent, while $14,7 \%$ think that it is "awful" \& "very terrible" When asked how they felt about this alternative considering their learning requirements. idea" 
Figure 3. What would be the benefits of a combination of teaching and online teaching?

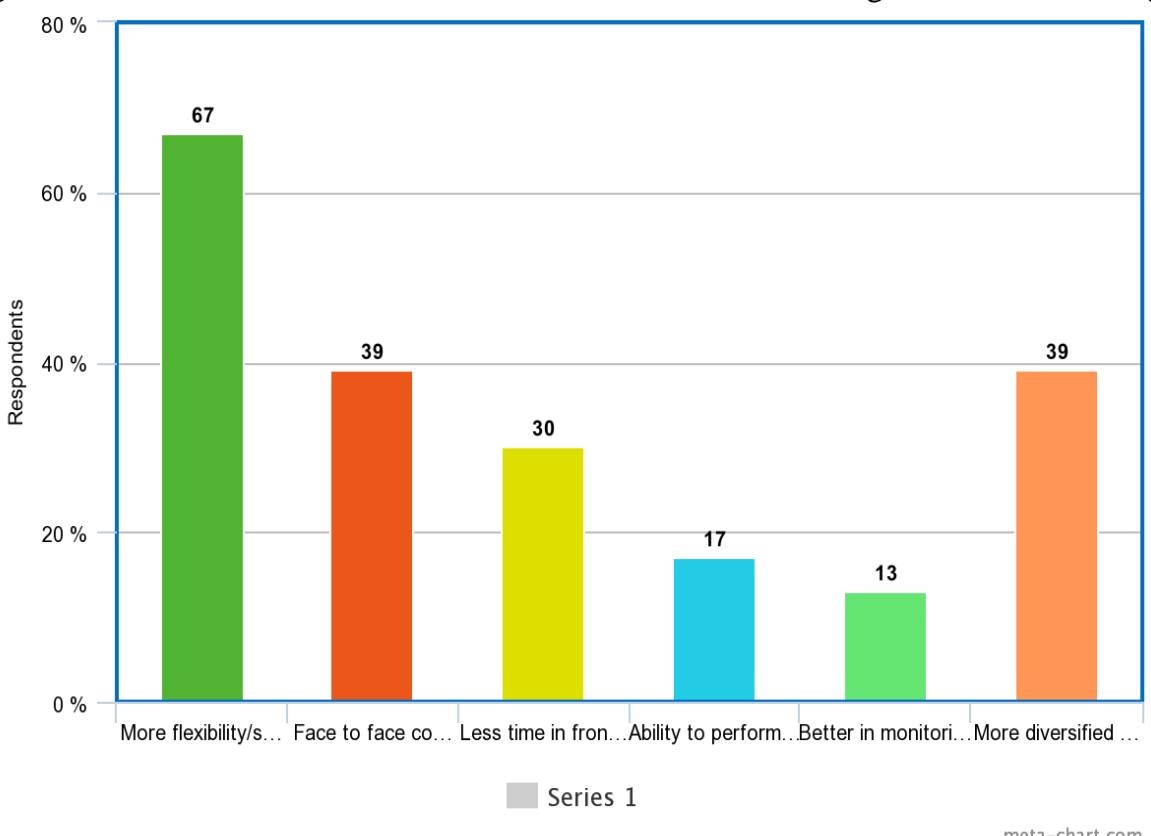

According to the results from figure 3, over 60 percent of the participants respond that the advantage of having class online is because of its flexibility. It indicates that reason why students like having online classes is because they can gain an advantage which they use that advantage to attend other affairs instead of performing a more efficient learning method.

Figure 4. Question 5: What would be the downsides of a combination of teaching and online teaching?

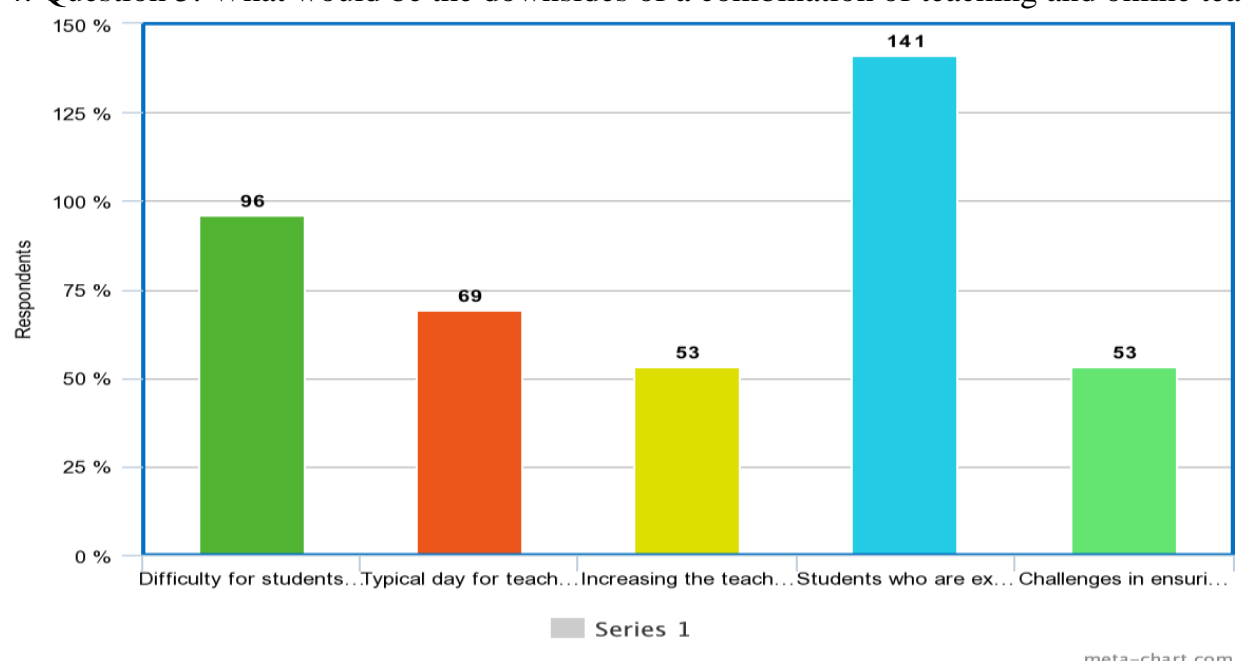

According to the results from Figure 4, the downside of combining the two forms of education include the students who are the "Students that do not have access to the right digital technology" which shows a sympathetic attitude towards their colleagues, despite being the second largely "student having difficulty adapting to this type of learning" and the third, "teacher has difficulty adapting to this kind of learning/appraisal." 
Figure 5. Question 6: Could you illustrate your perspective on online teaching given your experience during COVID-19?

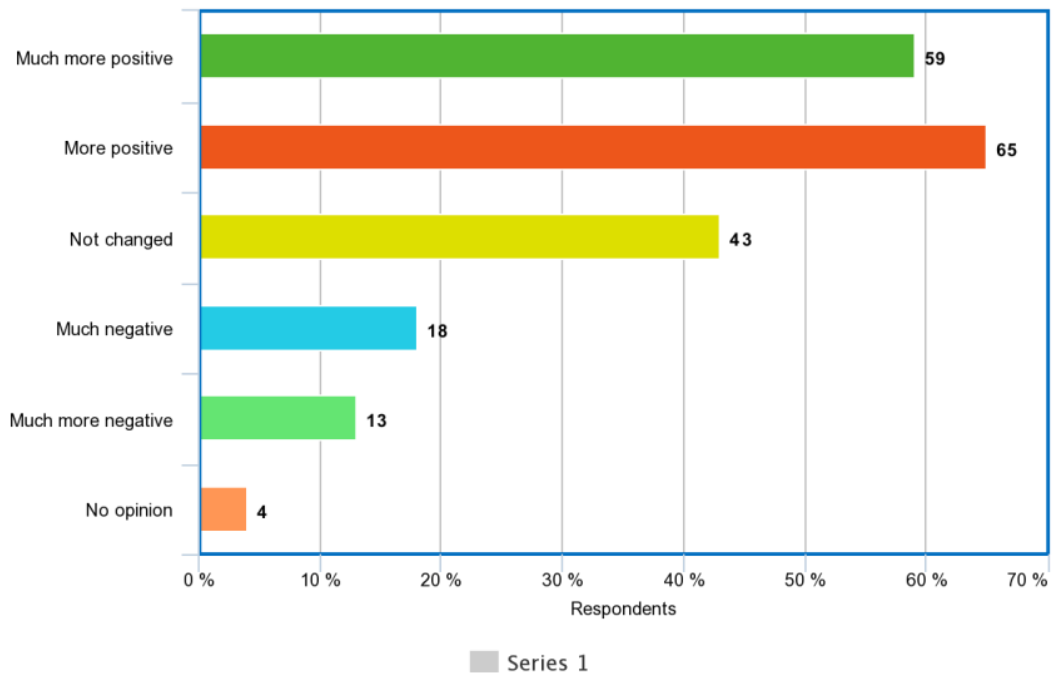

According to the results from figure 5, by considering these results, students desire additional freedom in the evaluation process (which online teaching can offer). They are nonetheless aware of the necessity and challenges of personal connection and communication between instructors and students. They are both infrastructure-based and competent online. When asked if the experience with COVID-19 had a bearing on their views on e-learning, 59 students responded that they "had much more favorable and 65 were more positive. They stated nothing had changed in 43 and in 31 they had a lot greater negative/detrimental effect. Four pupils did not voice their views.

Figure 6. Question 7: For future considerations, what would be the primary benefits of online teaching?

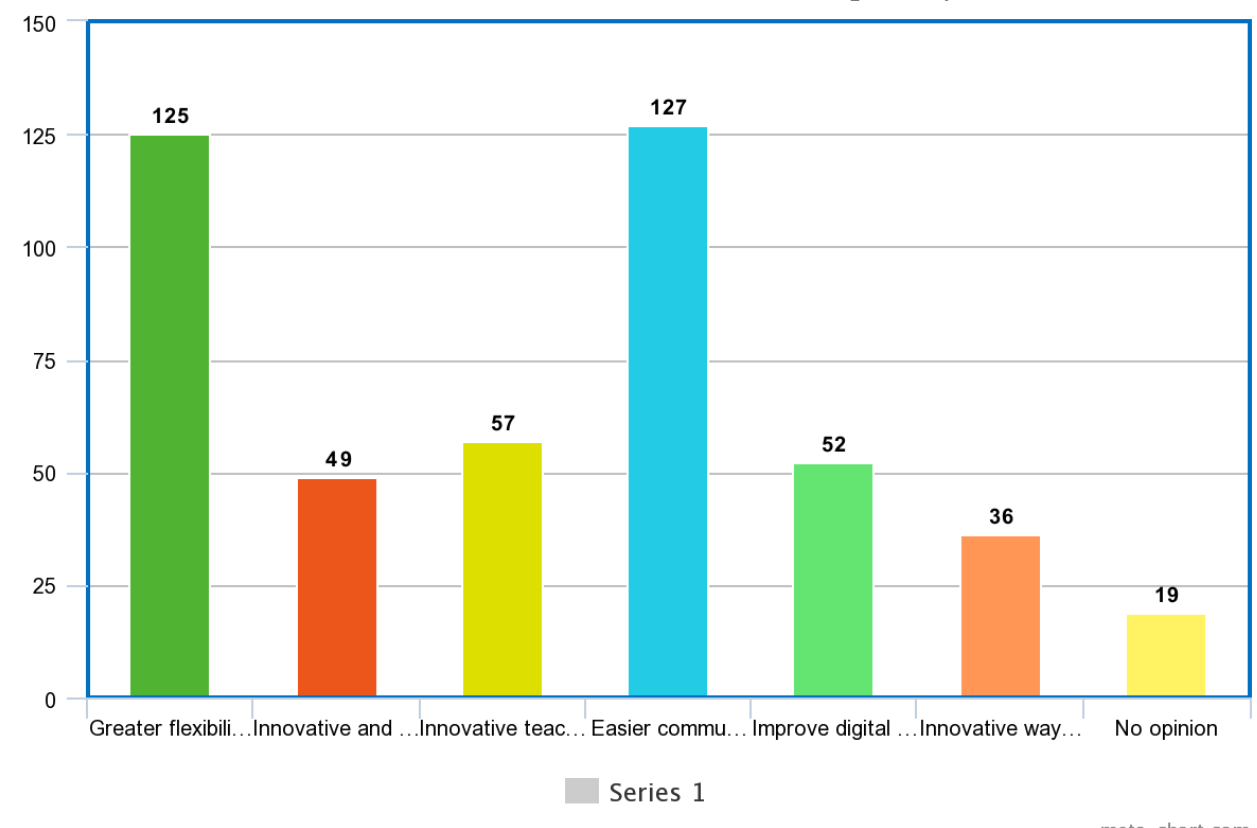


According to the results from figure 6, when 125 students questioned about the benefits of online learning in the future, they stated it gives "greater flexibility in teaching-learning" and adds to digital growth. 57 students then assessed the "new teaching learning instruments" and resources "which might be employed in the process of teaching.

Figure 7. Question 8: For future considerations, what do you think are the primary shortcomings of online teaching?

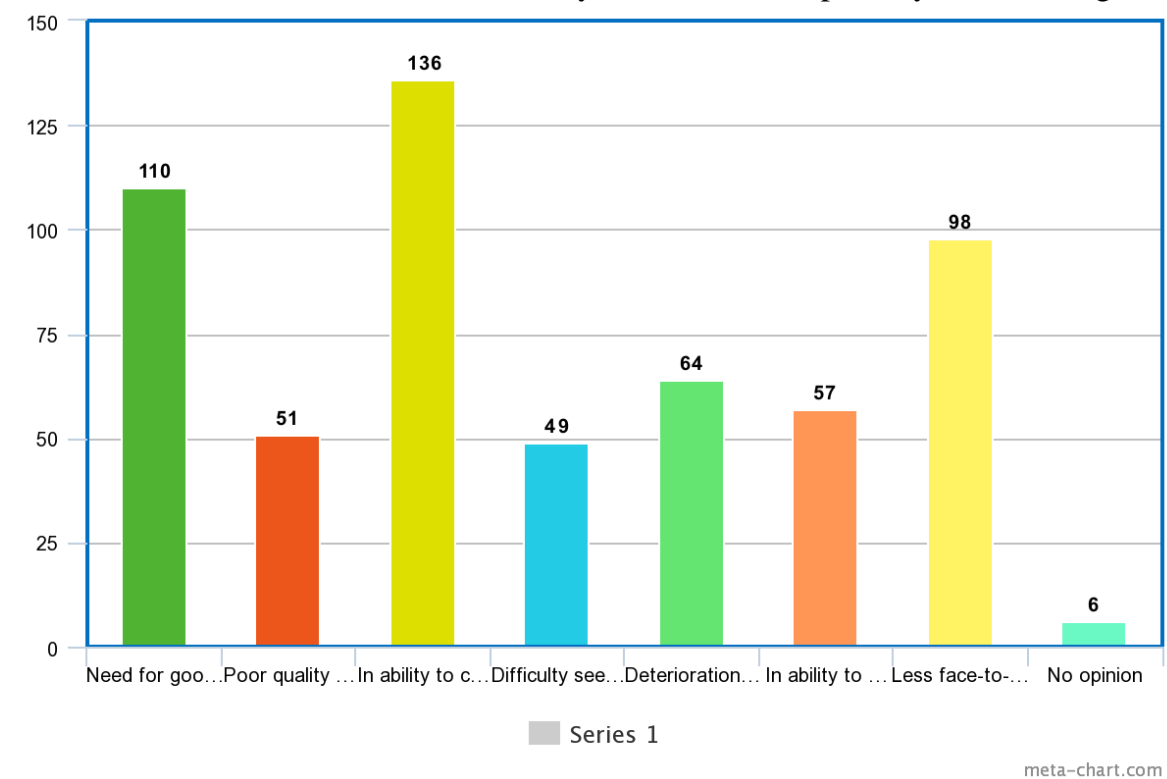

According to the results from figure 7, however, the major shortcoming of online teaching would be the "inability to perform practical uses.' Because of the distinct characteristics of both faculties, several disciplines apply in practice. To gain critical abilities, students rely on laboratory access. The university's people require specialized sports and training facilities, access to medical equipment and patient accommodation. Students in engineering need to understand technology, machinery and equipment, machine tools, etc.

Figure 8. Question 9: What factors do you think that online teaching resources and content are useful?

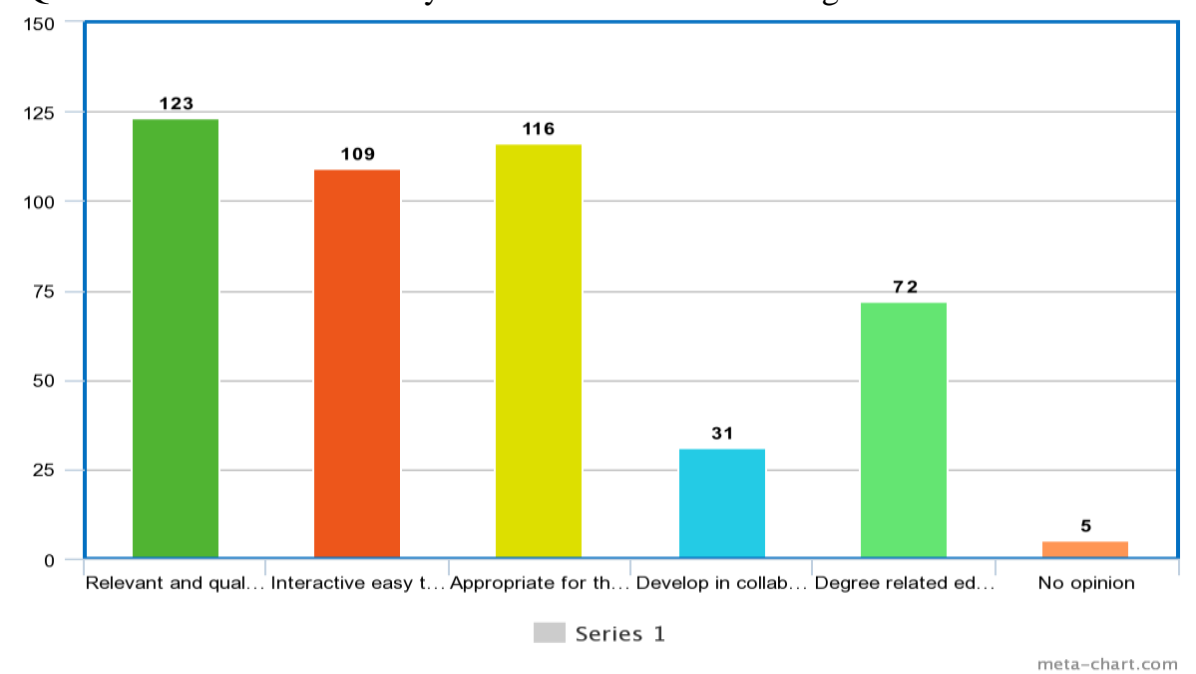


According to the results from figure 8, with relation to online education resources, students have relatively realistic and high expectations of these products. They must be relevant and quality, build competences that have a direct bearing on the demands of the labor market, and be interactive and easy to use.

The students were evaluated for their replies to the open-ended question (question 10), to identify what the students enjoyed in the online evaluation/examination. For example, 40.22 percent indicated that they did not have the stress/comfort associated with the examination; 17.92 percent underlined that there was more flexibility (the possibility to take the examination at different places, Examination criteria have been easier, e.g., for people who hold a job without missing a job). Improved digital abilities by 3.98 percent. Other advantages were creative evaluation/testing and even cheating possibilities during examinations, for example. $8.72 \%$ of students said that online assessment does not have the advantages and that some have not expressed their thoughts.

For question 11, which is the student's autonomous answer, regarding the online assessment/examination difficulties, the students raised the following questions: In this respect it should be mentioned that in the context of personal apprenticeship, both engineering and sport become students, both students should be assessed in practice applications d Lack (21.78 per cent) and adequate digital equipment (2.62 per cent), the potential fraud (14.32 per cent), the lack of personal interaction between the teacher and student (11.85 percent). Other responded shortcomings are subjective assessment (5.98 percent ), insufficient exam time (4.25 percent ), spending excessive amount of time with computer (1.76 percent ), shortage of motivation to learn (6.63 percent ), and 14.72 percent of the students confirmed that there are no disadvantages.

\section{CONCLUSION}

The study identified numerous unfavorable elements of the online education process growth at USC from the point of view of the student: (1) few pupils have the infrastructure they needed. Ensure that the teaching / learning process works properly. (2) Contact with teachers was not as efficient even though the infrastructure was established for most students. (5) inadequate testing of internet (e.g. fraudulent ability or subjective assessment); (6) lack of personal capacity to make a practical use; (4) lack of desire among students to study; (5) potential impairment of the mental and physical health (i. e. developing a sedentary lifestyle, a problem that many other students experienced). The socialization/connection and communicating with instructors and staff.

This poll was intended for graduate students in the Engineering and Common Schools of one of Los Angeles' leading private universities. The author of this study sought assistance with the survey design of the professors of the School of Engineering to best adapt this survey for these students. During the 
spring semester, the survey was carried out and all participants were Chinese students, which is why there was quite a few responses and the whole student body inside the USC was not represented.

Thirdly, at this moment the legitimacy of the actions taken cannot be checked. Therefore, in this semester I plan to have more participants to address more specific issues relating to student performance and well-being in terms of participating in crisis training through professional counseling services.

The research carried out shows that even though the University has taken necessary procedures to make sure the continuity of online teaching during the pandemic, there is still a long way to go before successfully implementing a truly effective online education system. The challenges that USC must face have nothing to do with the technical difficulty of inserting the system (in which it is already quite advanced). The research conducted reveals that while the university has made efforts to ensure the continuity of the education procedure during the pandemic, a really effective online education system still has a long way to go. The problems USC has to address are not related to the technological capability of establishing such a system, especially in the preparation of this kind of training proclamation of such the problem. 


\section{REFERENCES}

[1]. Atkeson, A. 2020. What will be the economic impact of COVID-19 in the U.S.? Rough estimates of disease sce- narios. No. w26867, National Bureau of Economic Research, Cambridge, MA.

[2]. Agnew, S., and S. Hickson. 2012. Using online assessment to replace invigilated assessment in times of a natural disaster: Are some online assessment conditions better than others? Journal of Open, Flexible, and Distance Learning $16(1): 1-13$.

[3]. Alhussain, Thamer. "How Technology Can Mitigate the Impact of COVID 19 on Education? A Case Study of Saudi Electronic University (SEU)." Journal of Theoretical and Applied Information Technology, vol. 98 , no. 21, 2020, pp. 3347-56.

[4]. Beech, Nic, and Frederik Anseel. "COVID-19 and Its Impact on Management Research and Education: Threats, Opportunities and a Manifesto." British Journal of Management, vol. 31, no. 3, Wiley Subscription Services, Inc, 2020, pp. 447-49, doi:10.1111/1467-8551.12421.

[5]. Bryson, J. R., and L. Andres. 2020. Covid-19 and rapid adoption and improvisation of online teaching: Curating resources for extensive versus intensive online learning experience. Journal of Geography in Higher Education. Advance online publication. doi: 10.1080/03098265. 2020.1807478.

[6]. Carter, F. A., C. J. Bell, A. N. Ali, J. McKenzie, and T. J. Wilkinson. 2014. The impact of major earthquakes on the psychological functioning of medical students: A Literature Cited Christchurch, New Zealand study. The New Zealand Medical Journal 127 (1398):54-66.

[7]. Chung, C. K. L., J. Xu, and M. Zhang. 2020. Geographies of Covid-19: How space and virus shape each other. Asian Geographer 37 (2):99-116. doi: 10.1080/10225706. 2020.1767423.

[8]. Collings, D., A. Garrill, and L. Johnston. 2018. Student application for special consideration for examination performance following a natural disaster. Assessment \& Evaluation in Higher Education 43 (2):260-71. doi:10.1080/02602938.2017.1332755.

[9]. Collings, D. A., J. A. Gerrard, and A. Garrill. 2019. Shaking up biology-Our experiences teaching cell biol- ogy and biochemistry to a first year undergraduate class through the Canterbury (New Zealand) earthquakes. Journal of Biological Education 53 (3):236-49. doi: 10. 1080/00219266.2018.1472134.

[10]. Day, T. 2015. Academic continuity: Staying true to teach- ing values and objectives in the face of course interrup- tions. Teaching \& Learning Inquiry: The ISSOTL Journal 3 (1):75-89. doi: 10.2979/teachlearninqu.3.1.75.

[11]. Dorn, E., Hancock, B., Sarakatsannis, J., \& Viruleg, E.. Covid-19 and education: The lingering effects of unfinished learning. McKinsey \& Company. Retrieved from https://www.mckinsey.com/industries/publicand-social-sector/our-insights/covid-19-and-education-the-lingering-effects-of-unfinished-learning.

[12]. Franchi, Thomas. "The Impact of the Covid-19 Pandemic on Current Anatomy Education and Future Careers: A Student's Perspective.” Anatomical Sciences Education, vol. 13, no. 3, Wiley Subscription Services, Inc, 2020, pp. 312-15, doi:10.1002/ase.1966.

[13]. Nic Dhonncha, E., and M. Murphy. "Learning New Ways of Teaching and Assessment: The Impact of COVID-19 on Undergraduate Dermatology Education." Clinical and Experimental Dermatology, vol. 46, no. 1, Wiley Subscription Services, Inc, 2021, pp. 170-71, doi:10.1111/ced.14364. 